\title{
Urząd pełnomocnika ds. równego traktowania jako element walki politycznej w Polsce
}

\begin{abstract}
Streszczenie: Urząd Pełnomocnika Rządu ds. Równego Traktowania został powołany w celu umacniania praktyki egalitarnej. Wprawdzie w Polsce urząd ten ma ponadtrzydziestoletnią historię, to jego pozycja i siła oddziaływania na prawodawstwo i życie społeczne - są niezadowalające. Jest to konsekwencją upolitycznienia urzędu i nadania jego funkcjonowaniu kontekstu ideologicznego. Świadczą o tym zmieniające się nazwy i personalia. Jedynie powołanie niezależnej pod względem politycznym, centralnej instytucji, która monitorowałaby kwestie związane z równouprawnieniem i jego naruszeniami, pozwoli na profesjonalizację urzędu. Dopóty, dopóki premier rządu decyduje o tym, kto sprawuje tę funkcję, urząd Pełnomocnika pozostanie elementem gry politycznej. Niniejszy artykuł stanowi próbę przybliżenia tego problemu poprzez analizę zmian, jakie przez trzy dekady zachodziły w zakresie funkcjonowania urzędu.
\end{abstract}

Słowa kluczowe: pełnomocnik ds. równego traktowania, równość, walka polityczna

$\mathbf{P}$ onieważ prawo stanowione w Polsce od dziesięcioleci gwarantowało równouprawnienie kobiet i mężczyzn, zmaskulinizowane elity polityczne nie widziały potrzeby wprowadzania rozwiązań konkretyzujących, a tym samym konfirmujących brak dyskryminacji ze względu na płeć. Przyczyny owej powściagliwości były zróżnicowane. Po pierwsze - brak świadomości problemu (Polska do tej pory podpisała wiele traktatów i konwencji, których treścią jest walka z dyskryminacją, nie ma zatem potrzeby mnożenia przepisów i urzędów; te, które istnieją - są wystarczające); po drugie - obawa przed konkurencją ze strony kobiet; po trzecie - powielana pokoleniowo świadomość dyskryminacyjna; po czwarte - lobbing Kościoła katolickiego, który aktywność w sferze działań egalitaryzujących, uznawał za potencjalne zagrożenie dla ,naturalnego porządku" społecznego (O’Brien, s. 27); po piąte - postrzeganie równouprawnienia poprzez prostą konotację komunistyczną (równouprawnienie kobiet i mężczyzn w państwach dawnego bloku wschod- 
niego kojarzyło się bowiem przede wszystkim z polityką i propagandą socjalistyczną, choć faktycznie w okresie PRL możemy mówić jedynie o ,pseudoemancypacji” (Heinen, 1997).

Jednak przystapienie Polski do Unii Europejskiej wiązało się z koniecznością przyjęcia obowiązujących w Europie standardów. Jednym z wymogów było powołanie urzędu, którego zadaniem byłaby autentyczna troska o równouprawnienie (jego celem byłoby wyeliminowanie wszelkich przejawów dyskryminacji, nie tylko ze względu na płeć, ale również: wiek, światopogląd, rasę, niepełnosprawność, orientację seksualną).

Należy podkreślić, że Polska, wśród państw byłego bloku wschodniego, pod tym względem była pionierem, bowiem już w 1986 roku powołano urząd Pełnomocnika Rządu ds. Kobiet. Decyzja ta była podyktowana strategią przyjętą w 1985 roku na Światowej Konferencji Kobiet w Nairobi i wpisywała się w harmonogram działań na rzecz poprawy statusu społeczno-zawodowego kobiet. Pierwszą Pełnomocniczką została Anna Kędzierska, która swój urząd pełniła do 1989 roku. Kędzierska, dzięki możliwości egzekwowania od poszczególnych ministerstw nałożonych zadań, mogła wykazać się konkretnymi osiągnięciami w sferze poprawy sytuacji kobiet, zwłaszcza na płaszczyźnie zawodowej. Niestety, ponieważ jej działalność nie była nagłaśniana przez media, również sukcesy nie były powszechnie znane (Krótka historia..., 2006).

Przez ponad 30 lat urząd wielokrotnie zmieniał swoją nazwę oraz zakres kompetencji, co odzwierciedlało stosunek kolejnych rządów RP do kwestii równościowej.

Do 2010 roku Pełnomocnik funkcjonował w oparciu o uchwałę lub rozporządzenie Rady Ministrów, a nie ustawę, co niewątpliwie stanowiło o słabości urzędu. Jego rangi nie podnosił również fakt, iż Pełnomocnicy nie byli ministrami, lecz najwyżej sekretarzami stanu przy urzędzie obsługującym ministra właściwego do spraw zabezpieczenia społecznego lub w Kancelarii Prezesa Rady Ministrów.

Także personalia symbolicznie definiowały politykę kolejnych rządów wobec zagadnień dyskryminacji ze względu na płeć.

W rządzie Jana Krzysztofa Bieleckiego oraz w gabinecie Jana Olszewskiego urząd Pełnomocnika Rządu ds. Kobiet i Rodziny pełniła prawniczka, Anna Popowicz. Popowicz sprawowała tę funkcję od kwietnia 1991 do marca 1992 roku. Warto podkreślić, iż Popowicz, mimo że była pełnomocnikiem rządu, nie należała do żadnej partii politycznej. Jeszcze w 1991 roku wystąpiła z „Solidarności”, do której należała od ponad dziesięciu lat. Dopiero po zakończeniu pełnienia urzędu wstąpiła do 
Kongresu Liberalno-Demokratycznego. Anna Popowicz, doprowadzając do uchwalenia przez Sejm RP rezolucji, przygotowała rządowy program działań na rzecz poprawy sytuacji kobiet, dzieci i rodzin (Polityka równości płci, 2007, s. 33).

Do 1995 roku, a więc przez trzy miesiące rządów Jana Olszewskiego, ponad rok rządów Hanny Suchockiej i półtora roku rządów Waldemara Pawlaka, Pełnomocnik nie był powoływany (rządy Hanny Suchockiej stanowił pewne kuriozum - w gabinecie pierwszej w historii Polski kobiety premiera nie było żadnej kobiety).

Dopiero premier Józef Oleksy powołał na urząd Pełnomocnika Rządu ds. Rodziny i Kobiet Barbarę Blidę, a wkrótce potem - Jolantę Banach, która pełniła tę funkcję do 1997 roku, a więc również w okresie rządów Włodzimierza Cimoszewicza (Nowakowska, 1990, s. 2). Jolanta Banach była, wraz z Danutą Waniek, współtwórczynią Demokratycznej Unii Kobiet. Po raz pierwszy do Sejmu kandydowała z listy Sojuszu Lewicy Demokratycznej, choć wcześniej była związana z „Solidarnością”. Jako Pełnomocnik, Banach powołała stałe Forum Współpracy Organizacji Pozarządowych i Pełnomocnika Rządu ds. Rodziny i Kobiety. Opracowała również „Krajowy program działań na rzecz kobiet do roku 2000”, który stanowił wypełnienie zaleceń Konferencji Pekińskiej. Ponadto, dzięki jej inicjatywie rząd opracował program przeciwdziałania przemocy w rodzinie: „Przeciw przemocy - wyrównać szanse”. Jolanta Banach nadzorowała również realizację tegoż programu, w oparciu o współpracę z biurem Programu Narodów Zjednoczonych ds. Rozwoju (UNDP) (Drewniak, 2012, s. 30).

W 1997 roku upada rząd SLD-PSL, a w wyniku wyborów parlamentarnych zawiązuje się nowa koalicja AWS-UW, na której czele staje Jerzy Buzek. Znamienne jest to, że na mocy rozporządzenia Prezesa Rady Ministrów, powstaje nowy urząd - Pełnomocnika Rządu ds. Rodziny, który zastąpił zarówno Pełnomocnika Rządu ds. Rodziny i Kobiet jak i Pełnomocnika Rządu ds. Dzieci. Priorytetowym zadaniem nowego Pełnomocnika było ,inicjowanie i koordynowanie działań na rzecz kształtowania i realizacji polityki państwa wobec rodziny" (Rozporządzenie Rady Ministrów z dnia 9 lutego 2001 roku). W rozporządzeniu określającym sferę działań pełnomocnika nie wspomniano nawet o kwestii równouprawnienia kobiet i mężczyzn. Nowy Pełnomocnik, Kazimierz Kapera (LPR), biorąc pod uwagę nową konwencję urzędu, był zatem odpowiednim kandydatem. Wcześniej, w rządzie J. K. Bieleckiego był wiceministrem zdrowia, jednak jego wypowiedź na temat homoseksuali- 
stów, których nazwał „zboczeńcami roznoszącymi AIDS” (Wywiad dla TVP...), doprowadziła do jego dymisji. W nowej roli Kazimierz Kapera zasłynął likwidacją programu „Przeciw przemocy - wyrównać szanse”, twierdząc, że przewidziane w nim priorytety są niewłaściwe. Wprawdzie zapowiedział przywrócenie Programu, ale po odpowiednich poprawkach. Kapera doprowadził również do wycofania dopłat do środków antykoncepcyjnych, ponieważ ,państwa nie stać na finansowanie czyjejś przyjemności i nieodpowiedzialności" (Czuchnowski, 2002). Z drugiej jednak strony - był gorącym zwolennikiem sprowadzenia do polskich aptek Viagry i dofinansowywania jej sprzedaży, co miałoby się przyczynić do poprawy przyrostu naturalnego (Ibidem). Jednak dopiero wypowiedź na temat „zaniku białej rasy” pod wpływem „,rasy żółtej i czarnej” (Ibidem), doprowadziła do jego dymisji, choć to nie premier Buzek pozbawił go urzędu, lecz miesiąc po rasistowskiej wypowiedzi sam Kapera zdecydował się odejść ze stanowiska (1999 r.).

Od 2000 roku urząd Pełnomocnika Rządu ds. Rodziny pełniła Maria Smereczyńska; z wykształcenia lekarka. Jej przynależność do Katolickiego Stowarzyszenia Lekarzy Polskich, Polskiej Federacji Stowarzyszeń Rodzin Katolickich, Ligi Małżeństwo Małżeństwu, Sekcji Obrony Życia Towarzystwa Lekarskiego (Ludzie..., 1999) oraz zasiadanie we władzach Polskiej Federacji Stowarzyszeń Rodzin Katolickich - w znaczący sposób definiuje sposób sprawowania przez nią urzędu. Jako Pełnomocnik, Maria Smereczyńska była, z jednej strony - orędowniczką pomocy dla wielodzietnych rodzin, $\mathrm{z}$ drugiej natomiast $-\mathrm{w}$ raporcie dotyczącym polityki prorodzinnej państwa (z 2001 r.) stwierdziła, że działania ówczesnego rządu przyniosły widoczne efekty w postaci wzrostu poziomu życia rodzin (Żyje nam się lepiej, 2001).

Wśród organizacji działających przeciwko dyskryminacji, Smereczyńska nie zdobyła uznania, głównie z powodu odmowy podpisania (na Komisji ONZ ds. Statusu Kobiet) „dokumentu przygotowanego przez UE, dotyczącego edukacji na rzecz tolerancji ze względu na pochodzenie, religię, niepełnosprawność i orientację seksualną. Właśnie wyróżnienie orientacji seksualnej spowodowało nie podpisanie tego dokumentu" (FIPress, 2001). Reprezentując Polskę na plenarnym posiedzeniu Nadzwyczajnej Sesji Narodów Zjednoczonych w Nowym Jorku, w swoich wystąpieniach zdecydowanie skrytykowała wszelkie formy aborcji z przyczyn społecznych, edukację seksualną oraz prawa nastolatków do prywatności i poufności (podobne stanowisko w czasie tej Sesji zajęły również: Liban, Nikaragua, Jemen, Sudan i Watykan) (Krótka historia..., 2006). 
Kolejne wybory parlamentarne w 2001 roku przyniosły zasadniczą zmianę na scenie politycznej. Dotychczasowe rządy centroprawicowe AWS i UW (od 2000 r. tylko AWS) zostają zastappione przez rząd lewicowy, do maja 2004 r. - Leszka Millera, a następnie, do października 2005 r. - Marka Belki. Już w 2001 roku urząd Pełnomocnika Rządu ds. Rodziny zastępuje Pełnomocnik ds. Równego Traktowania Kobiet i Mężczyzn, który miał być odpowiedzialny za zmiany w prawie, zgodne z perspektywą równości płci. Na nowy urząd zostaje powołana Izabela Jaruga-Nowacka (do 2004 r.), z wykształcenia etnograf, początkowo związana z SLD, od 2005 roku - bezpartyjna. W 2002 roku Jaruga-Nowacka powołała, jako ciało doradcze Pełnomocnika, Radę Programowo-Konsultacyjną. Rada, do momentu jej rozwiązania w 2006 roku, pełniła funkcję zespołu opiniodawczego i opiniotwórczego, a także ułatwiała komunikację między Urzędem a organizacjami pozarządowymi. Członkowie Rady decydowali (i decydują nadal) również o przyznaniu ,Szwedzkich Okularów Równości” - wyróżnienia, którym honorowano osoby prywatne, przedstawicieli mediów, instytucje wyróżniające się swoim zaangażowaniem w działalność na rzecz wyrównywania statusu mężczyzn i kobiet.

Przykładem aktywności Pełnomocnika było opracowanie „Krajowego Programu Działań na Rzecz Kobiet - II etap wdrożeniowy na lata 2003-2005". Na podstawie tego programu powołano wojewódzkich pełnomocników rządu ds. Równego Statusu Kobiet i Mężczyzn (Program..., s. 85). Przygotowano także projekt odrębnej ustawy o przeciwdziałaniu przemocy w rodzinie, która została uchwalona w 2005 roku. W związku z, przypadającym na czas funkcjonowania tego pełnomocnika, przystąpieniem Polski do UE, urząd ten zajmował się również przygotowywaniem szkoleń dla sędziów, policjantów, prokuratorów, urzędników administracji publicznej z zakresu problematyki gender mainstreaming.

Izabela Jaruga-Nowacka, jako Pełnomocnik Rządu ds. Równego Traktowania Kobiet i Mężczyzn, koncentrowała się na wprowadzeniu zmian do tzw. ustawy antyaborcyjnej, na edukacji seksualnej, zapłodnieniu in vitro, refundacji środków antykoncepcyjnych oraz na problemie praw człowieka (Drewniak, 2012, s. 21-22).

W 2004 roku Izabela Jaruga-Nowacka zrezygnowała z pełnienia funkcji Pełnomocnika, ponieważ została ministrem bez teki oraz wicepremierem ds. komunikacji społecznej. Na stanowisku zastapiła ją Magdalena Środa - filozofka, etyk, poetka, publicystka i feministka. Wprawdzie Środa sprawowała tę funkcję tylko kilka miesięcy, ale była bardzo wyrazistym i kontrowersyjnym Pełnomocnikiem. W grudniu 2004 roku, na kon- 
ferencji w Sztokholmie, poświęconej „zabójstwom honorowym”, prof. Środa stwierdziła, że w katolickiej Polsce nie ma problemu zabójstw honorowych, lecz są ,,problemy ze zjawiskiem stosowania przemocy wobec kobiet, mające źródło w silnym wpływie Kościoła katolickiego na życie publiczne", a katolicyzm, wprawdzie nie wspiera bezpośrednio, ale też nie sprzeciwia się jej stosowaniu (Magdalena Środa ..., 2004). Po tym wystąpieniu premier Belka zamierzał zdegradować Magdalenę Środę do rangi podsekretarza stanu (w tym momencie pełniła ona swój urząd w randze ministra), jednak Pełnomocniczka zagroziła, że poda się do dymisji, jako że tego typu działania godzą zarówno w urząd, jak i prawa kobiet. Wobec takiego dictum, premier odstapił od realizacji swego zamiaru. Magdalena Środa zasłynęła również zaangażowaniem w walkę z dyskryminacją kobiet w reklamach, zwłaszcza telewizyjnych. Jej zdaniem niektóre reklamy naruszają przepisy o równym traktowaniu kobiet i mężczyzn, zatem powinny zniknąć z mediów.

W okresie rządów lewicy w Polsce trzykrotnie były podejmowane próby ograniczenia kompetencji pełnomocnika. Po raz pierwszy, z inicjatywy Forum Kobiet Polskich. To katolickie stowarzyszenie, zgodnie $\mathrm{z}$,Deklaracją ideową”, koncentruje swoje działania na roli kobiety w rodzinie i społeczeństwie, problemach rodziny, małżeństwa, wychowania, na obronie życia ludzkiego od poczęcia do naturalnej śmierci oraz na obronie wartości religijnych i moralnych, inspiracje czerpiąc z nauki Kościoła katolickiego (Deklaracja ideowa..., 2009). Forum zażądało dymisji ówczesnej Pełnomocnik, Izabeli Jarugi-Nowackiej po tym, jak minister przedstawiła informację rządu na temat sytuacji kobiet w Polsce. Po raz drugi Liga Polskich Rodzin (w kwietniu 2003 roku) zaproponowała powołanie w miejsce istniejącego urzędu, Pełnomocnika Rządu ds. Rodziny. Trzeci przypadek dotyczył opisanej już sytuacji, związanej z prof. Środą i próbą degradacji podjętą przez premiera Belkę. I tym razem z inicjatywą odwołania Pełnomocnik wystapiło Forum Kobiet Polskich.

W wyniku zwycięstwa w wyborach parlamentarnych, w 2005 roku Prawa i Sprawiedliwości oraz powstania koalicji PiS, LPR, Samoobrona, premierem nowego rządu został Kazimierz Marcinkiewicz. W listopadzie 2005 roku podjął on decyzję o likwidacji urzędu, dając do zrozumienia, że jest to konsekwencją słynnej wypowiedzi Magdaleny Środy. Oficjalną przyczyną były jednak ,zmiany wynikające z Programu rządu na lata 2005-2009”. Przeciwko takiej decyzji zaprotestowało kilkadziesiąt polskich organizacji pozarządowych, jednakże protest ten nie przyniósł pożądanego efektu i na ponad 3 lata urząd Pełnomocnika przestał funkcjonować. 
Dopiero w marcu 2008 roku premier Donald Tusk powołał Pełnomocnika Rządu (tym razem) do Spraw Równego Traktowania. W rozporządzeniu Rady Ministrów z 22 kwietnia 2008 r. (Dz. U. z dn. 30 kwietnia 2008 r.) uwzględniono zadania antydyskryminacyjne Pełnomocnika, wynikające nie tylko z naruszenia zasady równości ze względu na płeć, ale również na rasę, pochodzenie etniczne, narodowość, religię lub wyznanie, poglądy polityczne, wiek, orientację seksualną, stan cywilny i rodzinny. Tak szerokie potraktowanie problemu zostało wymuszone zobowiązaniami Polski, wynikającymi z członkostwa w Unii Europejskiej, choć nie bez znaczenia były również starania i presja ze strony środowisk feministycznych oraz organizacji pozarządowych.

Pełnomocnikiem Rządu została Elżbieta Radziszewska - lekarka, politycznie związana z Unią Demokratyczną, Unią Wolności, a od 2001 roku - z Platformą Obywatelską. Radziszewska pełniła tę funkcję do 2011 roku, mimo że jej poczynania, czy raczej - zaniechania oraz wypowiedzi były bardzo krytycznie oceniane przez środowiska feministyczne i równościowe. Jako Pełnomocnik ds. Równego Traktowania, Radziszewska negatywnie wypowiadała się na temat wprowadzenia parytetu płci. Twierdziła, na przykład, że projekt zmian ordynacji wyborczej narusza dziesięć artykułów Konstytucji RP (Madejski, 2010). Pełnomocnik zarzucano również brak zaangażowania w kontynuację prac nad tzw. ustawą antydyskryminacyją (prace zaczęto w 2006 r.), mimo że Polska, jako członek UE była zobowiązana do uchwalenia takiego aktu, na mocy dyrektywy unijnej. W związku z zaniechaniem polskiego rządu w tej dziedzinie, Komisja Europejska skierowała na polski rząd skargę do Europejskiego Trybunału Sprawiedliwości. Elżbieta Radziszewska, pod groźbą kar, które mogłyby być na Polskę nałożone, obiecała, że ustawa powstanie do końca 2008 roku. To zobowiązanie nie zostało jednak dotrzymane. Jolanta Kluzik-Rostkowska określiła Radziszewską mianem ,fikcyjnego pełnomocnika" (Grochal, 2009). W podobny sposób o Pani Pełnomocnik wypowiadały się w środowiska równościowo-feministyczne.

Wprawdzie ustawa antydyskryminacyjna nie powstała do tej pory, ale jej namiastką jest przyjęta przez Parlament RP w 2010 roku ustawa o wdrożeniu niektórych przepisów Unii Europejskiej w zakresie równego traktowania (Dz. U. 2010, Nr 254, poz. 1700). Ustawą tą zobowiązano się do wdrożenia kilku dyrektyw UE, w tym dyrektywy 2006/54/WE w sprawie wprowadzenia w życie zasady równości szans oraz równego traktowania kobiet i mężczyzn w dziedzinie zatrudnienia i pracy oraz dyrektywy Rady 2000/78/WE z dnia 27 listopada 2000 r., ustanawiającej 
ogólne warunki ramowe równego traktowania w zakresie zatrudnienia i pracy. Ustawa z 2010 roku określała ogólne warunki ramowe polityki równego traktowania w Polsce i prawnie umacnia urząd Pełnomocnika Rządu do Spraw Równego Traktowania, który wcześniej podlegał rządowym aktom wykonawczym. Jako drugą centralną instytucję odpowiedzialną za realizację polityki równouprawnienia ustanowiono Rzecznika Praw Obywatelskich.

Jednak ustawa z 2010 stanowiła krok wstecz w stosunku do wcześniejszych projektów, które zakładały powołanie niezależnej politycznie instytucji centralnej, monitorującej prawo i praktykę równouprawnienia. Fakt, że Pełnomocnik jest powoływany i odwoływany przez premiera oraz sprawuje swój urząd w randze sekretarza stanu w Kancelarii Prezesa Rady Ministrów - nie gwarantuje niezależności urzędu. Ponadto ustawodawca jednoznacznie stwierdził odnośnie jakich sfer ustawy się nie stosuje. Jest to zatem np. sfera życia prywatnego i rodzinnego, treści zawarte w mediach, usługi edukacyjne w zakresie dotyczącym odmiennego traktowania ze względu na płeć. Zgodnie z oceną Komitetu ONZ ds. Likwidacji Dyskryminacji Kobiet, dotyczącą wdrożenia rzeczonej konwencji, ustawa „nie zapewnia ochrony przed dyskryminacją ze względu na płeć i płeć kulturową w takich dziedzinach, jak edukacja, opieka zdrowotna oraz życie prywatne i rodzinne", a także ze względu na różne, wzajemnie powiązane formy dyskryminacji (ONZ, 2014, p. 10).

Opinia Komitetu ONZ nie wpłynęła na zmianę przepisów ustawy z 2010 roku. W 2011 roku urząd Pełnomocnika Rządu ds. Równego Traktowania objęła Agnieszka Kozłowska-Rajewicz - z wykształcenia biolog (doktorat $\mathrm{z}$ antropologii), związana z PO. W czasie pełnienia funkcji Pełnomocnika Kozłowska-Rajewicz skupiała się na problemie wykluczenia na rynku pracy osób powyżej 50. roku życia oraz ułatwieniu powrotu do aktywności zawodowej młodym matkom. W czasie, gdy Kozłowska-Rajewicz pełniła funkcję Pełnomocnika, Polska podpisała (grudzień 2012) Konwencję Rady Europy o zapobieganiu i zwalczaniu przemocy wobec kobiet i przemocy domowej. Przez środowiska prawicowe Pełnomocnik była krytykowana za wypowiedzi o „rodzinnocentrycznym” typie polskiego społeczeństwa i propagowanie wprowadzenia do szkół i przedszkoli edukacji seksualnej oraz edukacji równościowej, a także za objęcie patronatem publikacji Lekcja równości wydanej przez Kampanię Przeciw Homofonii. Kozłowska-Rajewicz była także autorką projektu PO dotyczącego tzw. ustawy parytetowej. Jednak, ponieważ posłowie Platformy nie mogli dojść do porozumienia odnośnie zgłaszanych propozycji, pro- 
jekt Rajewicz nie został złożony, choć pewne propozycje, zostały włączone w formie poprawki do projektu obywatelskiego. $Z$ tego powodu część środowisk feministycznych krytykowała Pełnomocniczkę za odejście od parytetu na rzecz rozwiązania kwotowego. W 2014 roku, Agnieszka Kozłowska-Rajewicz dostała się z list PO do Parlamentu Europejskiego. Zrezygnowała więc $\mathrm{z}$ pełnionego urzędu.

W lipcu tegoż roku na urząd Pełnomocnika Rządu ds. Równego Traktowania Premier powołał Małgorzatę Fuszarę, bezpartyjną prawniczkę i socjolożkę, cieszącą się dużym szacunkiem w środowiskach równościowych. Profesor Fuszara od wielu lat zajmuje się problematyką gender, jest również współautorką pierwszego projektu ustawy o równym statusie kobiet i mężczyzn, który był wnoszony do Parlamentu dwukrotnie, w 1996 i 1997 roku. Podczas gdy urząd Pełnomocnika pełniła Elżbieta Radziszewska, krytyczne wobec niej środowiska feministyczne i równościowe wskazywały na jej następczynię właśnie prof. Fuszarę.

Wybór i działalność nowej Pełnomocnik wywoływały negatywne reakcje i krytyczne komentarze ze strony środowisk prawicowych i katolickich. Zarzucano jej, iż nie czyni nic, aby ograniczyć dyskryminacje matek, które zdecydowały się poświęcić wychowaniu dzieci, a nie pracy zarobkowej. W zamian Pani Pełnomocnik miała promować rozwiązania „zniechęcające kobiety do wychowywania dzieci”. Chodziło tutaj o stwierdzenie Pani Minister, iż niedowartościowanie pracy domowej kobiet jest konsekwencją ,negatywnych wzorców kulturowych”, co, zdaniem prawicowego Instytutu Ordo Iris, oznacza deprecjację zaangażowania kobiet w macierzyństwo (Minister Fuszara ..., 2015).

Prof. Fuszara skrytykowała również ówczesnego wiceministra sprawiedliwości, Michała Królikowskiego za wypowiedź, iż „pojęcie godności w polskiej Konstytucji należy rozumieć zgodnie z tradycją chrześcijańską". W związku z tym środowiska katolickie przestrzegały, przed ideologizacją (,genderyzm”) urzędu Pełnomocnika. Na jej wybory ideologiczne wpływ miał mieć fakt, że jest panną („starą") i nie ma dzieci (Środa, 2016).

W czasie, gdy minister Fuszara pełniła swoją funkcje, opozycja kilkakrotnie przypominała jej wypowiedź na temat kazirodztwa, która rzekomo padła w czasie konferencji pt. „Nienormatywne praktyki rodzinne”. Pełnomocnik miała poddawać w wątpliwość zasadność utrzymania zakazu związków kazirodczych w kontekście rodzicielstwa. Podważając kompetencje nowej Pełnomocnik, prezes PiS, Jarosław Kaczyński, zarzucił prof. Fuszarze, że promuje lewactwo, a tym samym „podnosi rękę 
na polską rodzinę, podnosi rękę na Polskę". W odpowiedzi na te zarzuty Pełnomocnik stwierdziła, że jej wypowiedź została zmanipulowana ,ponieważ zanim padły te słowa, wyjaśniła ona, że na Zachodzie toczy się debata nad wszelkimi przesłankami uniemożliwiającymi małżeństwa. Wśród tych przesłanek są związki rodzinne" (Rozmowa Krzysztofa Krzeszowskiego..., 2014).

Zmiana na stanowisku Pełnomocnika Rządu ds. Równego Traktowania, po wygranych w 2015 roku przez PiS wyborach parlamentarnych, była więc oczekiwana. Prof. Fuszara zrezygnowała $z$ tej funkcji wraz z powołaniem nowego rządu. Przez kilkanaście tygodni urząd pozostawał nieobsadzony, co nie tylko było niezgodne z ustawą z 2010 roku, ale również groziło sankcjami unijnymi. W styczniu 2016 roku Pełnomocnikiem Rządu ds. Rozwoju Społeczeństwa Obywatelskiego i ds. Równego Traktowania został Wojciech Kaczmarczyk. Zatem nie tylko zmieniła się osoba Pełnomocnika, ale po raz kolejny zmieniono nazwę urzędu i zakres zadań. Nowego Pełnomocnika przedstawił wicepremier Piotr Gliński jako osobę o doświadczeniu akademickim, naukowym i eksperckim, a przede wszystkim zaangażowaną w prace organizacji pozarządowych (niestety, autorka artykułu nie dotarła do informacji na temat wykształcenia W. Kaczmarka) (Wojciech Kaczmarczyk..., 2016).

Głównym zadaniem nowego Pełnomocnika miało być przygotowanie nowego programu rozwoju społeczeństwa obywatelskiego, monitorowanie i wdrażanie tego programu oraz współpraca państwa z NGO. Wśród wymienianych przez ministra Kaczmarczyka priorytetów nie ma zagadnień związanych ze sferą działalności pełnomocnika ds. równego traktowania. Minister Kaczmarczyk, jako nowy Pełnomocnik rządu, zasłynął wypowiedzią, której sens zaskakiwał w kontekście sprawowanego urzędu. Odpowiadając na Facebooku na pytania dotyczące wolności gospodarczej i świadczenia usług, Pełnomocnik stwierdził, że „Zarówno kupującego, jak i sprzedawcy nie można zmusić do zawarcia transakcji, której nie chce". Na pytanie internauty, czy hotelarz może odmówić osobie czarnoskórej świadczenia usług, odpisał: „nie sądzę, aby prawo powinno tu cokolwiek nakazywać albo zakazywać" (Czy można odmówić sprzedaży..., 2016).

Przez kilka miesięcy pełnienia urzędu Pełnomocnika Wojciech Kaczmarczyk wielokrotnie formułował opinie, które spotykały się krytyczną oceną nie tylko środowisk równościowych, ale również części opinii publicznej. Podczas VIII Kongresu Kobiet Kaczmarczyk aczkolwiek stwierdził, że udoskonalenia wymaga ,system instytucjonalno-prawne- 
go wsparcia kobiet wychowujących przez dłuższy czas dzieci, zarówno w etapie wychowania, kiedy poświęcają się edukacji, jak też w elastycznym, najbardziej efektywnym i przyjaznym dla kobiet powrocie do pracy" (cyt. za: Petnomocnik rzqdu... 2016), to jednak wyraził przekonanie, iż, obowiązujące w Polsce prawo, gwarantuje ,,pełną ochronę praw kobiet i umożliwia im wszechstronny rozwój" (Ibidem). Najwięcej kontrowersji wywołało jednak stwierdzenie, iż ,szklane sufity są jedynie w głowach samych kobiet” (Ibidem). Należy wszakże podkreślić, iż Wojciech Karczmarczyk wypowiedział te słowa, przytaczając niejako wypowiedzi szefów spółek skarbu państwa. Jednak Pełnomocnik, jako remedium na ów problem, wskazuje swoistą akcję uświadamiającą możliwość awansu, prowadzoną przez kobiety, które sukces osiągnęły. W podobnym duchu Wojciech Kaczmarczyk wypowiedział się w trakcie wywiadu z dziennikarką „Gazety Wyborczej”. Wprawdzie wywiad ten nie był autoryzowany, jednak redakcja, powołując się na wyrok Trybunału Konstytucyjnego z dnia 28 września 2008 (SK 52/05), zdecydowała się na opublikowanie omówienia tej rozmowy (Siedlecka, 2016). Wywiad opatrzono następującym lidem streszczającym: „Badania nad homofobią są nierzetelne; aptekarze mogą odmawiać sprzedaży antykoncepcji; niepełnosprawnym nie jest potrzebna skarga na niewykonywanie konwencji ONZ o ich prawach" (Ibidem). W trakcie niespełna ośmiomiesięcznego sprawowania urzędu W. Kaczmarczyk, zarówno w swych wypowiedziach, jak i poprzez konkretne działania, potwierdził swoje usytuowanie w strukturach rządowych, sekundując wykładni ideowej partii rządzącej.

Mimo to we wrześniu 2016 roku Wojciech Kaczmarczyk został odwołany, a jego miejsce, 5 października, zajął wiceprezes PiS, Adam Lipiński - wieloletni, bliski współpracownik prezesa Prawa i Sprawiedliwości, Jarosława Kaczyńskiego, z wykształcenia ekonomista, który w 2015 roku, po raz szósty zasiadł w ławach poselskich. Wybór ten był zaskoczeniem zarówno dla opozycji politycznej, jak i organizacji pozarządowych. Dotychczas Adam Lipiński był sekretarzem stanu w Kancelarii Prezesa Rady Ministrów, odpowiedzialnym z współpracę rządu i parlamentu. Decyzja premier Beaty Szydło przez media została więc potraktowana jako swoista degradacja Lipińskiego, która miałaby być konsekwencją słabnącej pozycji wiceprezesa w partii. Tym samym został zdefiniowany stosunek obecnej władzy do urzędu Pełnomocnika. Urząd ten zdaje się być „złem koniecznym", wymuszonym poprzez zobowiązania międzynarodowe. Również obecna koncepcja sprawowania tej funkcji, realizowana przez A. Lipińskiego, wydaje się potwierdzać tę tezę. Nowy Pełnomocnik uni- 
ka mediów, nie zajmuje stanowiska w istotnych, z punktu widzenia jego obowiązków, kwestiach. Nie jest kontrowersyjny, ale też nie wykazuje determinacji $\mathrm{w}$ podejmowanych działaniach. $\mathrm{Na}$ stronie internetowej Pełnomocnika możemy znaleźć informacje o jego aktywności: udziale w obchodach Międzynarodowego Dnia Holokaustu przed Pomnikiem Bohaterów Getta w Warszawie, spotkaniu z pełnomocnikami wojewodów zajmującymi się współpracą z III sektorem w związku z projektem ustawy o Narodowym Centrum Rozwoju Społeczeństwa Obywatelskiego. Nie znajdziemy jednak przejawów aktywności, które powinny wynikać $\mathrm{z}$ pełnionego urzędu.

Od momentu powołania Pełnomocnika Rządu ds. Kobiet w 1986 roku, nazwa tego urzędu (i oczekiwania związane z jego funkcjonowaniem) zmieniała się ośmiokrotnie. Zmiany te nie były jedynie kosmetyczne. To, jakie słowa i w jakiej kolejności sytuowały się w nazwie urzędu, w jaki sposób rozkładano akcenty podczas definiowania kompetencji Pełnomocnika, ma bezpośredni związek z koncepcją polityki równościowej danego rządu. (partie lub koalicje partii o konotacjach prawicowokonserwatywnych eksponowały zagadnienie „rodziny”, partie lewicowe - „równości”). Również fakt, iż Pełnomocnika powołuje premier rządu nie sprzyja niezależności tej instytucji. Można odnieść wrażenie, że polska elita polityczna nie rozumie konieczności istnienia niezależnego urzędu, który będzie dbał o konkretyzację praw zagrożonych dyskryminacją grup społecznych.

\section{Bibliografia}

Czuchnowski W. (2002), Człowiek, który powiedział za dużo, „Gazeta Wyborcza” $\mathrm{z}$ dn. 18.10 .

Czy można odmówić sprzedaży z powodu koloru skóry? Petnomocnik rzqdu PiS ds. równości daje zielone światto dyskryminacji, (2016), http://natemat. pl/179441,czy-mozna-odmowic-sprzedazy-z-powodu-koloru-skory-pelnomocnik-ds-rownosci-rzadu-pis-daje-zielone-swiatlo-dyskryminacji.

Deklaracja ideowa Forum Kobiet Polskich (2009), Kobieta w świecie wspótczesnym, www.forumkobietpolskich.csc.pl/deklaration.php.

Drewniak E. (2012), Wptyw kobiet na politykę państwa na przyktadzie Polski i Hiszpanii, Promotor, Kraków.

FIpress (2001), Raport o dyskryminacji, wrocław.ngo.pl/wiadomość/37151.html.

Grochal R. (2009), Kobiety nie chcq kwiatka, wyborcza.pl/1,75398,7264452,Kobiety_nie_chca_kwiatka.html. 
Heinen J. (1997), Public/Private. Gender, Social and POlitical Citizenship in Eastern Europe, „Theory and Society” 26 (4), s. 577-597.

Krajowy Program Działań na Rzecz Kobiet - II etap wdrożeniowy na lata 2003-2005, rownosc.ngo.pl/files/równość.ngo.pl/public/prawo_polskie/KrajowyProgram.pdf.

Krótka historia urzędu Pełnomocnika (2006), Ślaska strefa gender, www.gender.pl/ readarticle.php?article_id=38.

Ludzie. Maria Smereczyńska (1999), https://www.wprost.pl/tygodnik/5442/Ludzie.html.

Madejski D. (2010), Sejmowa debata o parytecie rozpoczęta, e-prawnik.pl/wiadomości/informacje/sejmowa-debata-o-parytecie-rozpoczetaa.html.

Magdalena Środa zostaje (2004), Bnakier.pl, www.bankier.pl/wiadomosci/Magdalena-Sroda-zostaje-1232322.html.

Minister Fuszara przeciwko wychowywaniu dzieci przez matki, http://www.fronda.pl/a/ minister-fuszara-przeciwko-wychowywaniu-dzieci-przez-matki,54730.html.

Nowakowska U. (1990), Instrumenty państwa na rzecz awansu kobiet, w: Kobiety $w$ Polsce - w latach 90, http://www.webcache.googleusercontent.com.

O'Brien G. D. (2010), The Chuch and abortion: a catholic dissent, Rowman \& Littlefield Publishers, Maryland.

ONZ (2014), Konwencja w sprawie likwidacji wszelkich form dyskryminacji kobiet. Uwagi końcowe dotyczace połaczonego siódmego i ósmego sprawozdania okresowego Polski, Komitet ds. Likwidacji Dyskryminacji Kobiet.

Petnomocnik rzqdu ds. równego traktowania wybuczany na Kongresie Kobiet, www. rp.pl/Kraj/160519605-Pelnomocnik-rzadu-ds-rownego-traktowania-wybuczany-na-Kongresie-Kobiet.html\#ap-1.

Polityka równości płci. Raport (2007), Program Narodów Zjednoczonych, Warszawa.

Rozmowa Krzysztofa Grzesiowskiego Małgorzatą Fuszara, Małgorzata Fuszara: nigdy nie popierałam kazirodztwa, oczekuje przeprosin, www.polskieradio. pl/7/129/Artykuł/1251008,malgorzata-Fuszara-nigdy-nie-popieralam-kazirodztwa-oczekuje-przeprosin.

Rozporządzenie Rady Ministrów z dnia 22 kwietnia 2008 r. w sprawie Pelnomocnika Rzadu do spraw Równego Traktowania, Dz. U. 2008, Nr 75, poz. 450.

Rozporządzenie Rady Ministrów z dnia 9 lutego 2001 r. w sprawie Petnomocnika Rzqdu do Spraw Rodziny, Dz. U. 2001, Nr 10, poz. 74.

Siedlecka E. (2016), Równość według Wojciech Kaczmarczyka, petnomocnika rzqdu ds. równego traktowania, wyborcza.pl/magazyn/1,24059,20031971,rownoscwedlug-wojciecha-kaczmarczyka-pelnomocnika-rzadu-ds.html.

Środa M. (2016), Cała prawda, tė prawda i..., http://wyborcza.pl/1,75968, 20390521,cala-prawda-tez-prawda-i.html.

Wojciech Kaczmarczyk pełnomocnikiem rzqdu ds. społeczeństwa obywatelskiego $i$ równego traktowania, https://www.premier.gov.pl/wydarzenia/aktualnosci/wojciech-kaczmarczyk-pelnomocnikiem-rzadu-ds-spoleczenstwaobywatelskiego-i-html. 
Wywiad dla TVP z dn. 7 maja $1991 \mathrm{r}$.

Żyje nam się lepiej (2001), www.rmf24.pl/ekonomia/news-zyje-nam-sie-lepiej,nId,113319.

\title{
The Office of the Plenipotentiary for Equal Treatment as part of the political struggle in Poland
}

\begin{abstract}
Summary
The Office of the Plenipotentiary for Equal Treatment was established to strengthen the practice of egalitarian. While in Poland, the office has more than 30-yearold, its position and influence on legislation and social life are unsatisfactory. This is a consequence of the politicization of the office and giving the ideological context to its functioning. This is evidenced by the changing names and personal details. Until the Prime Minister decides who performs this function, the Office of the Plenipotentiary will remain as a part of the political game. This article is an attempt to approximate this problem by analyzing the changes that have occurred over three decades in the functioning of the Office.
\end{abstract}

Key words: Office of the Plenipotentiary for Equal Treatment, equality, political struggle 